\title{
ANALISIS KEMAMPUAN FISIK ATLET TINJU AMATIR KALIMANTAN BARAT
}

\author{
Fakihani Berrezokhy ${ }^{1}$, Uray Gustian ${ }^{2 *}$, Isti Dwi Puspitawati ${ }^{3}$ \\ ${ }^{1,2,3}$ Program Studi Pendidikan Kepelatihan Olahraga, Fakultas Keguruan dan Ilmu Pendidikan \\ Universitas Tanjungpura, Jln. Prof. Dr. H. Hadari Nawawi, Pontianak \\ *e-mail: uray.gustian@fkip.untan.ac.id
}

\begin{abstract}
Abstrak
Penelitian ini bertujuan untuk mengetahui peningkatan kemampuan fisik atlet tinju amatir Kalimantan Barat yang dipersiapkan untuk menghadapi ajang prakualifikasi Pon 2019. Metode yang digunakan dalam penelitian ini adalah metode survey dengan teknik pengumpulan data mengunakan tes dan pengukuran terhadap komponen biomotor dominan. Adapun subjek dalam penelitian ini adalah seluruh atlet tinju amatir Kalimatan Barat yang dipersiapkan untuk menghadapi praPon tinju amatir dengan jumlah sebanyak 10 atlet. Analisis data dalam penelitian ini munggunakan statistik deskriptik kuantitatif dan uji beda (uji T). Hasil penelitian menunjukan komponen biomotor dominan antara sebelum dan setelah melakukan (TC) training center tidak ada perbedaan yang significant atau dengan kata lain tidak ada perubahan yang artinya tidak terjadi peningkatan kemampuan komponen biomotor dominan. Kesimpulannya tidak terjadi peningkatan kemampuan fisik atlet tinju amatir Kalimantan Barat selama mengikuti persiapan prakualifikasi Pon 2019.
\end{abstract}

Kata kunci: atlet tinju, komponen biomotor, tes dan pengukuran

\begin{abstract}
This study aims to find out the development of physical ability of West Kalimantan amateur boxing athletes in preparation of Pra Qualification for PON 2019. The method used in this study was survey method. The tests and measurements of dominant biomotor components were used to collect the data. The subjects in this study were 10 West Kalimantan amateur boxing athletes in preparation of Pra Qualification for Pon 2019. The Data analysis in this study were Quantitative Descriptive Statistic and T-Test. The finding of this study: there were no significant differences of dominant biomotor components before and after training center. The conclusion: there was no increasing level of physical ability of West Kalimantan amateur boxing athletes during the preparation of Pra Qualification for Pon 2019.
\end{abstract}

Keywords: boxing athletes, biomotor components, tests and measurements

\section{PENDAHULUAN}

Tinju amatir merupakan salah satu olahraga beladiri yang berasal dari luar negeri dan bekembang di Indonesia. Setiap olahraga beladiri memiliki karakter dan ciri khas tersendiri menyesuaikan dengan kebutuhannya (Pahlevi, 2012). Dalam pertandingan tinju amatir seorang petarung dituntut untuk mengumpulkan point secepat dan sebanyak mungkin agar dapat mengungguli lawannya. Olahraga tinju amatir memiliki durasi pertandingan yang cepat yakni terdiri atas tiga ronde dan berdurasi tiga menit di setiap rondenya dengan waktu istirahat 1 menit 
disetiap ronde (Saripin, 2017). Seorang atlet tinju amatir dituntut memiliki kecepatan gerak untuk menunjang penampilannya dalam melakoni pertandingan (Loda, 2017). Menurut Muis (2016), kebutuhan tersebut dapat terpenuhi dengan prasyarat seorang atlet tinju amatir memiliki kondisi fisik yang baik terutama pada komponen biomotor dan sistem energi dominan.

Kondisi fisik yang baik bagi atlet tinju amatir merupakan hal yang sangat dibutuhkan untuk menunjang penampilannya saat melakoni pertandingan, terutama pada komponen biomotor dominan mulai dari kekuatan otot lengan, koordinasi gerakan daya tahan memukul dan kecepatan reaksi (Muis, 2016). Selain itu, waktu pertandingan tinju yang pendek dan juga dengan intensitasnya yang tinggi mengakibatkan atlet tinju amatir juga membutuhkan derajat kebugaran anaerobik dan perkembangan sistem anaerobik yang baik (predominan sistem energi) (Lumba, 2018). Oleh kerena itu, agar semua tuntutan kebutuhan tersebut dapat teratasi atlet tinju amatir sangat membutuhkan kondisi fisik yang baik untuk dapat meraih prestasinya (Latuheru, 2018).

Pembinaan kondisi fisik merupakan cara yang harus dilakukan dalam upaya pencapain kondisi fisik yang baik, mengetahui potensi dan mengembangkanya higga maksimal merupakan modal yang dapat digunakan sebagai patokan dalam membuat landasan untuk melakukan pembinaan fisik dari mana harus dimulai (Fardiansah, 2015). Untuk mengetahui potensi yang dimiliki oleh atlet dalam melakukan pembinaan fisik dapat dilakukan dengan cara melakukan tes dan pengukuran terhadap komponen biomotor dominan.

Pertina Kalimantan Barat merupakan induk organisasi yang menaungi olahraga tinju amatir di Kalimantan Barat (Kal-Bar). Pembinaan latihan fisik yang dilakukan Pertina Kal-Bar selama ini dilaksanakan dengan cara dimandatkan sepenuhnya kepada pelatih dalam proses pelaksanaanya. Latihan fisik selama ini dilakukan berdasarkan program latihan yang telah dibuat oleh pelatih. Seluruh atlet yang dilatih dituntut untuk mengikuti seluruh rangkaian program latihan tersebut dengan dosis dan standar yang telah dibuat tanpa mengetahui terlebih dahulu status awal komponen biomotor dominan atlet setiap individu. 
Model pembinaan latihan seperti ini diharapkan mampu meraih prestasi ditingkat Pekan Olahraga Nasional (PON). Prestasi yang diraih dari 15 tahun terakhir di 3 kesempatan ajang pesta olahraga terbesar di Indonesia sekalipun belum pernah meraih mendali emas, prestasi tinju amatir Kal-Bar pada Pon Kalimatan Timur 2008 meraih 1 medali perak, pada kesempatan Pon riau 2012 Kal-Bar berhasil meraih satu medali perunggu. Pada kesempatan PON Jawa Barat 2016 kalbar berhasil meraih 2 medali perunggu dikategori putra. PON merupakan ajang olahraga paling bergengsi di Indonesia dan atlet yang berhak untuk mengikuti ajang ini terlebih dahulu harus melewati ajang seleksi yakni PRAPON yang merupakan ajang seleksi wajib yang harus diikuti para atlet untuk mendapatkan tiket ke PON. Prestasi yang dicapai masih belum termasuk pada kategori yang membanggakan. Untuk itu, perlu dilakukan upaya lebih lanjut untuk meningkatkan pencapaian prestasi atlet tinju amatir Kal-Bar.

Berdasarkan permasalahan tersebut, perlu dilakukan penelitian untuk mengukur kemampuan biomotor dominan atlet tinju amatir Kal-Bar guna untuk mengetahui kualitas kondisi fisik secara menyeluruh. Penelitian dilakukan dengan cara tes dan pengukuran status awal dan akhir dari komponen biomotor dominan atlet Pertina Kal-Bar dalam rangka persiapan menghadapi PraPon 2019. Penelitian ini bertujuan untuk mengetahui sejauh mana peningkatan status komponen biomotor dominan mulai dari sebelum dan setelah melakukan TC. Hasil dari penelitian diharapkan dapat dijadikan masukan bagi pelatih dan pengurus Pertina Kal-Bar dalam mengevaluasi keberhasilan pelaksanaan latihan yang telah dilakukan.

\section{METODE}

Metode penelitian ini mengunakan metode survey dengan tes dan pengukuran. Metode survey merupakan salah satu metode penelitian kuantitatif, metode ini bertujuan untuk melihat keadaan yang menjadi objek penelitian dengan melihat data dan informasi yang ada dalam sampel, tanpa memberikan perlakuan (treatment) khusus sesuai dengan kondisi sesungguhnya (Indrawan dan Yuniawati, 2016). Metode ini digunakan peneliti untuk mengetahui kualitas 
kemampuan fisik sampel dalam penelitian dan tanpa adanya perlakuan (treatment) peneliti. Teknik pengambilan sampel dalam penelitian ini menggunakan teknik sampling jenuh, sehingga sampel dalam penelitian ini adalah seluruh atlet tinju amatir Kalimantan Barat yang dipersiapkan untuk menghadapi prapon 2019 yang berjumlah 10 atlet.

Teknik pengumpulan data mengunakan tes dan pengukuran komponen biomotor dominan yang terbagi menjadi dua tahap mulai dari sebelum dan setelah melakukan Training Center (TC). Adapun komponen biomotor dominan yang akan diukur terdiri dari enam komponen pertama kekuatan otot yang terdiri dari kekuatan otot lengan menggunakan pull and push test, otot tangan mengunakan hand grip test, otot tungkai dan otot togog back and leg dynamometer test, otot perut mengunakan sit-up. Kedua respon speed yang tediri dari anticipation reaction time test dan whole body reaction time test. Ketiga agility mengunakan quick feet test. Keempat keseimbangan yang terdiri dari standind stork test dan standing stork test blind,. Kelima fleksibilitas mengunakan sit and reach test, dan Keenam daya tahan mengunakan multi-stage fitnes test (Adiatmika \& Santika, 2015; Mackenzie, 2005; Syaquro dan badruzaman. 2016).

Teknik analisis data mengunakan analisis deskriptif dan uji beda (uji t). Analisis deskriptif digunakan sebagai media untuk menyampaikan fakta-fakta dan fenomina apa saja yang terjadi selama proses penelitian berlangsung sehingga data yang diperoleh sesuai dengan keadaan yang terjadi dalam proses penelitian yang dilakukan. Uji beda (uji t) digunakan sebagai alat uji pembanding data hasil penelitian yang dilakukan mulai dari pre-test hingga posttest.

\section{HASIL DAN PEMBAHASAN}

\section{Hasil}

Deskripsi data tentang hasil analisis kemampuan fisik yang dilakukan dengan cara melakukan tes dan pengukuran terhadap komponen biomotor dominan mulai dari kekuatan otot, respon speed, agility, keseimbangan, fleksibilitas dan daya tahan yang terbagi menjadi dua tahap yaitu tahap pertama 
pretes sebeluam atlet melakukan Training Center (TC) dan tahap kedua setelah atlet melakukan Training Center (TC).

\section{Kekuatan otot}

Hasil analisis kemampuan komponen biomotor kekuatan sebelum (pretest) dan sesudah menjalani TC (posttest) disajikan pada Tabel 1.

Tabel 1 Distribusi Frekuensi Pre-test dan Posttest Biomotor Kekuatan

\begin{tabular}{cccccc}
\hline \multirow{2}{*}{ Penilaian } & Standar & \multicolumn{4}{c}{ Frekuensi } \\
\cline { 3 - 6 } & Skor & & \multicolumn{2}{c}{ Pretest } & \multicolumn{2}{c}{ Postest } \\
\cline { 3 - 6 } & & Absolut (Fa) & Relatif (\%) & $\begin{array}{c}\text { Absolut } \\
(\text { Fa) }\end{array}$ & Relatif (\%) \\
\hline Baik sekali & $>4.9$ & 0 & $0 \%$ & 0 & $0 \%$ \\
Baik & $4.0-4.9$ & 1 & $10 \%$ & 0 & $0 \%$ \\
Cukup & $3.0-3.9$ & 6 & $60 \%$ & 6 & $60 \%$ \\
Kurang & $2.0-2.9$ & 3 & $30 \%$ & 4 & $40 \%$ \\
Kurang sekali & $<1.9$ & 0 & $0 \%$ & 0 & $0 \%$ \\
\hline
\end{tabular}

Berdasarkan Tabel 1, terlihat bahwa pencapaian kategori kemampuan komponen biomotor kekuatan sebelum dan sesudah menjalani TC lebih dominan berada pada kategori cukup dan kategori kurang.

\section{Respon speed}

Hasil analisis kemampuan komponen biomotor respon speed sebelum (pre-test) dan sesudah menjalani TC (posttest) disajikan pada Tabel 2.

Tabel 2 Distribusi Frekuensi Pre-test dan Posttest Biomotor Respon Speed

\begin{tabular}{cccccc}
\hline \multirow{2}{*}{ Penilaian } & \multirow{2}{*}{$\begin{array}{c}\text { Standar } \\
\text { Skor }\end{array}$} & \multicolumn{3}{c}{ Pretest } & \multicolumn{2}{c}{ Postest } \\
\cline { 3 - 6 } & & Absolut (Fa) & Relatif (\%) & Absolut (Fa) & Relatif (\%) \\
\hline Baik sekali & $>4.9$ & 0 & $0 \%$ & 0 & $0 \%$ \\
Baik & $4.0-4.9$ & 1 & $10 \%$ & 1 & $10 \%$ \\
Cukup & $3.0-3.9$ & 4 & $40 \%$ & 5 & $50 \%$ \\
Kurang & $2.0-2.9$ & 2 & $20 \%$ & 4 & $40 \%$ \\
Kurang sekali & $<1.9$ & 3 & $30 \%$ & 0 & $0 \%$ \\
\hline
\end{tabular}

Tabel 2 menunjukkan bahwa kemampuan komponen biomotor respon speed sebelum menjalani TC (pre-test) lebih dominan berada pada kategori cukup dan kategori kurang sekali. Sedangkan kemampuan komponen biomotor respon speed sesudah menjalani (posttest) lebih dominan berada pada kategori cukup dan kategori kurang. 


\section{Agility}

Hasil analisis kemampuan komponen biomotor agility sebelum (pre-test) dan sesudah menjalani TC (posttest) disajikan pada Tabel 3.

Tabel 3 Distribusi Frekuensi Pre-test dan Posttest Biomotor Agility

\begin{tabular}{cccccc}
\hline \multirow{2}{*}{ Penilaian } & Standar & \multicolumn{4}{c}{ Frekuensi } \\
\cline { 3 - 6 } & Skor & & \multicolumn{2}{c}{ Pretest } & \multicolumn{2}{c}{ Postest } \\
\cline { 3 - 6 } & & Absolut (Fa) & Relatif (\%) & $\begin{array}{c}\text { Absolut } \\
(\text { Fa) }\end{array}$ & Relatif (\%) \\
\hline Baik sekali & $>4.9$ & 2 & $20 \%$ & 8 & $80 \%$ \\
Baik & $4.0-4.9$ & 0 & $0 \%$ & 1 & $10 \%$ \\
Cukup & $3.0-3.9$ & 5 & $50 \%$ & 0 & $0 \%$ \\
Kurang & $2.0-2.9$ & 2 & $20 \%$ & 0 & $0 \%$ \\
Kurang sekali & $<1.9$ & 1 & $10 \%$ & 1 & $10 \%$ \\
\hline
\end{tabular}

Tabel 3 menunjukkan bahwa kemampuan komponen biomotor agility sebelum menjalani TC (pre-test) lebih dominan berada pada kategori cukup. Sedangkan hasil analisis kemampuan komponen biomotor agility setelah menjalani menjalani TC pencapain kategori lebih dominan berada pada kategori baik sekali.

\section{Keseimbangan}

Tabel 4 menyajikan hasil analisis kemampuan komponen biomotor keseimbangan sebelum (pre-test) dan sesudah menjalani TC (posttest).

Tabel 4 Distribusi Frekuensi Pre-test dan Posttest Biomotor Keseimbangan

\begin{tabular}{|c|c|c|c|c|c|}
\hline \multirow{3}{*}{ Penilaian } & \multirow{3}{*}{$\begin{array}{l}\text { Standar } \\
\text { Skor }\end{array}$} & \multicolumn{4}{|c|}{ Frekuensi } \\
\hline & & \multicolumn{2}{|c|}{ Pretest } & \multicolumn{2}{|c|}{ Postest } \\
\hline & & Absolut (Fa) & Relatif (\%) & Absolut (Fa) & Relatif (\%) \\
\hline Baik sekali & $>4.9$ & 0 & $0 \%$ & 0 & $0 \%$ \\
\hline Baik & $4.0-4.9$ & 0 & $0 \%$ & 0 & $0 \%$ \\
\hline Cukup & $3.0-3.9$ & 1 & $10 \%$ & 1 & $10 \%$ \\
\hline Kurang & $2.0-2.9$ & 0 & $0 \%$ & 3 & $30 \%$ \\
\hline Kurang sekali & $<1.9$ & 9 & $90 \%$ & 6 & $60 \%$ \\
\hline
\end{tabular}

Tabel 4 menunjukkan bahwa kemampuan komponen biomotor keseimbangan sebelum dan sesudah menjalani TC lebih dominan berada pada kategori kurang sekali. Hal ini menunjukkan bahwa kemampuan komponen biometer keseimbangan atlet setelah menjalani TC masih tergolong rendah. 


\section{Fleksibilitas}

Tabel 5 menyajikan hasil analisis kemampuan komponen biomotor fleksibilitas sebelum (pre-test) dan sesudah menjalani TC (posttest).

Tabel 5 Distribusi Frekuensi Pre-test dan Posttest Biomotor Fleksibilitas

\begin{tabular}{|c|c|c|c|c|c|}
\hline \multirow{3}{*}{ Penilaian } & \multirow{3}{*}{$\begin{array}{l}\text { Standar } \\
\text { Skor }\end{array}$} & \multicolumn{4}{|c|}{ Frekuensi } \\
\hline & & \multicolumn{2}{|c|}{ Pretest } & \multicolumn{2}{|c|}{ Postest } \\
\hline & & Absolut (Fa) & Relatif (\%) & Absolut (Fa) & Relatif (\%) \\
\hline Baik sekali & $>4.9$ & 6 & $60 \%$ & 3 & $30 \%$ \\
\hline Baik & $4.0-4.9$ & 0 & $0 \%$ & 5 & $50 \%$ \\
\hline Cukup & $3.0-3.9$ & 3 & $30 \%$ & 1 & $10 \%$ \\
\hline Kurang & $2.0-2.9$ & 1 & $10 \%$ & 0 & $0 \%$ \\
\hline Kurang sekali & $<1.9$ & 0 & $0 \%$ & 1 & $10 \%$ \\
\hline
\end{tabular}

Tabel 5 menunjukkan bahwa kemampuan komponen biomotor fleksibilitas sebelum menjalani (TC) (pre-test) lebih dominan berada pada kategori baik sekali sedangkan kemampuan komponen biomotor fleksibilitas sesudah menjalani TC (posttest) pencapain kategori lebih dominan berada pada kategori baik.

\section{Daya tahan}

Tabel 6 menyajikan hasil analisis kemampuan komponen biomotor daya tahan sebelum (pre-test) dan sesudah menjalani TC (posttest).

Tabel 6 Distribusi Frekuensi Pre-test dan Posttest Biomotor Daya Tahan

\begin{tabular}{|c|c|c|c|c|c|}
\hline \multirow{3}{*}{ Penilaian } & \multirow{3}{*}{$\begin{array}{c}\text { Standar } \\
\text { Skor }\end{array}$} & \multicolumn{4}{|c|}{ Frekuensi } \\
\hline & & \multicolumn{2}{|c|}{ Pretest } & \multicolumn{2}{|c|}{ Postest } \\
\hline & & Absolut (Fa) & Relatif (\%) & Absolut (Fa) & Relatif (\%) \\
\hline Baik sekali & $>4.9$ & 0 & $0 \%$ & 0 & $0 \%$ \\
\hline Baik & $4.0-4.9$ & 0 & $0 \%$ & 0 & $0 \%$ \\
\hline Cukup & $3.0-3.9$ & 1 & $10 \%$ & 2 & $20 \%$ \\
\hline Kurang & $2.0-2.9$ & 6 & $60 \%$ & 7 & $70 \%$ \\
\hline Kurang sekali & $<1.9$ & 3 & $30 \%$ & 1 & $10 \%$ \\
\hline
\end{tabular}

Tabel 6 menunjukkan bahwa kemampuan komponen biomotor daya tahan sebelum dan sesudah menjalani TC lebih dominan berada pada kategori kurang. Namun sebanyak tiga atlet yang sebelumnya berada pada kategori kurang sekali setelah menjalani TC menjadi berkurang yaitu satu orang yang berada pada kategori kurang sekali. 
Berdasarkan Tabel 7, diketahui bahwa rata-rata nilai pre-test lebih tinggi dibandingkan rata-rata nilai posttest. Hal ini menunjukkan bahawa kemampuan biometer dominan atlet lebih baik sebelum menjalani TC.

Tabel 7 Nilai Rata-Rata $(\overline{\mathbf{x}})$ dan Standar Deviasi (SD) Data Pre-tes dan Pos-tes

\begin{tabular}{cccccc}
\hline \multicolumn{2}{c}{ Indikator } & $\begin{array}{c}\text { Rata-rata } \\
(\overline{\mathbf{x}})\end{array}$ & $\begin{array}{c}\text { Skor } \\
\text { Terendah }\end{array}$ & $\begin{array}{c}\text { Skor } \\
\text { Tertinggi }\end{array}$ & $\begin{array}{c}\text { Standar } \\
\text { Deviasi } \\
(\text { SD) }\end{array}$ \\
\hline $\begin{array}{c}\text { Komponen } \\
\text { Biomotor } \\
\text { Dominan }\end{array}$ & Pretest & 46,2 & 43 & 49 & 1,98 \\
\hline
\end{tabular}

Selanjutnya dilakukan uji t. Hasil uji t seperti yang disajikan pada Tabel 8, diketahui bahwa nilai signifikansi sebesar 0.368 lebih besar dari 0.005 , hal ini menunjukkan bahwa tidak ada perbedaan antara data pre-test dan posttest. Berdasarkan hasil analisis uji beda dari data tes kemampuan komponen biomotor dominan atlet tinju amatir Kalimantan Barat yang dipersiapkan untuk menghadapi ajang praPon tinju 2019 tidak terjadi perubahan atau peningkatan yang signifikan dari sebelum hingga seseudah mengikuti TC.

\section{Tabel 8 Hasil Analisis Uji Beda Pre-test dan Posttest}

Komponen Biomotor Dominan

\begin{tabular}{ccc}
\hline Variabel & Sig & Level of significant \\
\hline Pre-test \& Posttest Komponen Biomotor Dominan & 0.368 & 0.005 \\
\hline
\end{tabular}

\section{Pembahasan}

Penelitian ini bertujuan untuk mengetahui peningkatan kemampuan fisik atlet tinju amatir Kalimantan Barat dengan cara melakukukan tes dan pengukuran terhadap komponen biomotor dominan yang mencakup kekuatan, respon speed, agility, keseimbangan, fleksibilitas, dan daya tahan mulai dari sebelum dan setelah menjalani TC yang diadakan Pertina Kalimantan Barat dalam rangka persiapan menghadapi ajang praPon tinju.

Hasil penelitian berdasarkan data pre-test dan posttest secara keseluruhan komponen biomotor yang telah dianalisis dengan uji beda menunjukan bahwa tidak ada perbedaan antara data pre-test dan posttest yang dapat diartikan bahwa 
tidak terjadi peningkatan kemampuan fisik atau peningkatan kemampuan komponen biomotor domoinan dari data pre-tes dan pos-tes. Hasil penelitian menunjukan tidak ada perubahan atau peningkatan kemampuan komponen biomotor atlet tinju amatir Kalimantan Barat dan cenderung menurun. Hasil ini membuktikan bahwa kurang memuaskannya pencapaian prestasi atlet tinju PERTINA Kalimantan Barat salah satunya disebabkan kemampuan komponen biomotor atlet yang belum berada pada level sangat baik. Hal ini dikarenakan kemampuan komponen biomotor merupakan bagian dari kondisi fisik dan kondisi fisik merupakan faktor terbesar dalam penentu keberhasilan pencapaian prestasi atlet tinju (Latuheru, 2018; De Osmon, \& Sin, 2019).

Hasil penelitian yang diperoleh menunjukan bahwa TC yang dilakukan oleh PERTINA Kalimantan Barat belum memberikan dampak positif terhadap peningkatan kemampuan biomotor atle. Seperti yang diketahui, TC merupakan upaya yang telah tersusun dan terencana dengan rapi oleh pihak penanggung jawab yang akan melaksanakanya, dengan tujuan memfokuskan atlet untuk berlatih dengan program latihan yang telah dipersiapkan dan juga untuk mempermudah dalam pemantauan hasil perkembangan dari latihan yang dilakukan. Program latihan merupakan salah satu faktor terjadinya peningkatan dari hasil latihan. TC dilakukan sebagai upaya meningkatan komponen biomotor ketingkat yang setinggi-tingginya dengan harapan atlet dapat meraih prestasi tertingginya dapat ditempuh dengan cara melakukan latihan kondisi fisik (Harsono, 2015).

Selain itu, dalam pemilihan jenis latihan dan sistem energi utama (predominan system energi) yang dipakai dalam latihan dan saat bertanding merupakan prasyarat utama yang harus dilakukan agar latihan yang dilakukan dapat menghasilkan sebuah peningkatan dan efektivitas latihan dapat tercapai (Kurdi \& Sukirno, 2011). Proses latihan yang dilakukan agar dapat menghasilkan sebuah peningkatan, prinsip pembebanan berlebih merupakan prasyarat yang harus dilakukan untuk menghasilkan peningkatan dari proses latihan yang dilakukan tersebut (Lubis, 2013). Selain itu, untuk efektivitas tercapainya 
peningkatan hasil latihan juga perlu dilakukan evaluasi tes agar target latihan dapat termonitor degan mudah (Owen et al., 2016).

Akan tetapi, hal tersebut bukanlah satu-satunya faktor penentu tercapainya peningkatan prestasi atlet. Faktor yang lain seperti recovery, cedera dan gizi juga memiliki peranan penting yang harus diperhatikan kualitasnya demi tercapainya keberhasilan peningktan prestasi. Tidak ada perubahan atau peningkatan kemampuan komponen biomotor atlet tinju amatir Kalimantan Barat sebenarnya tidak murni hanya karena efektivitas program latihan saja melainkan ada beberapa faktor yaitu atlet pada saat mengikuti tes dan pengukuran dilakukan tidak mampu menampilkan kemapuan maksimalnya, Hal tersebut disebabkan terdapat beberapa atlet yang mengalami cedera dan juga ada yang lagi proses penurunan berat badan sehingga atlet tidak bisa menampilkan kemampuan maksimalnya, yang berakibat pada tidak adanya perbedaan dari hasil analisis uji beda atau dengan kata lain tidak ada peningkatan kemampuan komponen biomotor antara pre-test dan posttest.

Faktor lainnya penunjang keberhasilan atlet dalam meningkatkan prestasi atlet tinju amatir Kalimantan Barat adalah pembagian waktu dan pemberian porsi (intensitas) latihan. Oleh kerena itu, dalam mengambil keputusan untuk kedua faktor penunjang keberhasilan atlet harus mengacu pada periodesasi latihan dimana setiap fase latihan memili karakter dan kebutuhan tersendiri (Lubis, 2013: 4). Intesitas dan durasi merupakan komponen latihan yang harus selalu ditinggkatan agar selama proses latihan berlangsung dapat menghasilkan peningkatan kondisi fisik yang ditargetkan (Stöggl \& Björklund, 2017).

Intensitas yang dipakai saat latihan minimal intensitas pembebanan latihan $60 \%$ dari kamampuan maksimal dan juga harus selalu ditingkatkan hingga sampai fase kompetisi utama. Hal dapat memicu terjadinya kelelahan pada atlet dan berdampak pada penurunan performa dan optimalisasi kesiapan atlet untuk mengikuti latihan berikutnya (Harsono, 2015: 79). Disamping itu, intensitas latihan yang semakin berat dan selalu ditingkatkan disetiap peralihan fase latihan merupakan salah satu faktor penyebab terjadinya cedera pada atlet (Bagaswara dan Priyonoadi, 2015). 
Terjadinya cedera mulai dari sistem energi, otot dan fraktur dalam dunia olahraga adalah hal yang sering terjadi dan sangat erat hubungnya dengan kesiapan kondisi fisik atlet untuk berlatih, hal ini dapat mengakibatkan menurunya performa atlet dalam berlatih yang pada akhirnya dapat berdampak pada penurunan prestasi atlet (Putri, 2019). Intensitas latihan yang selalu ditingkatkan disetiap peralihan fase latihan hingga kompetisi utama bukanlah faktor utama penjamin tercapainya peningkatkan prestasi atlet, bahkan hal ini dapat berbanding terbalik hasilnya ketika dilakkan tanpa adanya recovery untuk mengatasi kelelahan tubuh dan kerusakan otot yang diakibatkan oleh tingginya intensitas latihan tersebut (Harsono, 2015: 89). Oleh kerena itu, seorang atlet yang sedang berlatih memerlukan istirahat (recovery) untuk mengatasi kelelahanya, yang dapat berdampak baik pada pemulihan dan perkembangan ototnya yang telah mengalami kerusakan akibat dari proses latihan yang dilakukan (Bafirman, 2013).

Dilihat dari jenisnya recovery terbagi menjadi dua jenis yaitu recovery aktiv dan pasif dimana keduanya memiliki tujuan dan fungsi khusus tersendiri, meskipun pada dasarnya memiliki fungsi yang sama yaitu memulihkan kondisi fisik dan meminimalisir terjadinya cedera (Parwata, 2015). Recovery aktiv merupakan latihan pemulihan kondisi fisik yang bertujuan untuk membantu otot membersihkan asam laktat yang dihasilkan dari aktivitas fisik dengan intensitas tinggi, yang dapat dilakukan dengan cara jogging dengan intensitas rendah (Lubis, 2013: 87). Recovery pasif merupakan pemulihan dengan cara mengistirahatkan tubuh dari aktivitas fisik yang dapat dilakukan dengan cara alternatif seperti massage (Widhiyanti, 2019).

Berlatih dengan kedisiplinan tingkat tinggi dan terprogram adalah hal yang harus dilakukan oleh atlet guna menghasilkan latihan yang berkualitas agar dapat mempertahankan kondisi fisiknya sebagai penunjang peningkatan prestasi, tercapainya latihan yang berkualitas berbanding lurus dengan ketersediaan energi dalam tubuh yang diperoleh dari asupan nutrisi dari makanan yang dikonsumsi atlet (Arsani, 2014). Gizi merupakan salah satu faktor biologis yang berpengaruh dalam menunjang prestasi atlet (Faruq dan Adiningsih, 2017). Gizi yang baik 
bagi atlet selain dari kualitas makanan itu sendiri juga harus mengacu pada kebutuhan kondisi fisik atlet perindividu, selain itu juga harus menyesuaikan dengan pereodesasi latihan yang sedang berjalan demi efektivitas penyerapan nutrisi sesuai dengan kebutuhan demi tercapainya peningkatan prestasi yang diharapkan (Hasbullah dkk, 2017). nutrisi yang baik bagi atlet dapat memberikan dampak positive pada prestasi atlet khususnya pada pemulihan sistem energi yang telah habis karena menjalankan latihan yang berat (Jeukendrup, 2017).

\section{SIMPULAN}

\section{Simpulan}

Berdasarkan hasil analisis data penelitian dapat ditarik kesimpulan bahwa tidak terjadi peningkatan dari hasil tes dan pengukuran kemampuan komponen biomotor dominan yang dilakukan mulai dari sebelum dan sesudah menjalani TC dalam rangka menghadapi ajang praPon 2019. Terjadinya hal tersebut diakibatkan oleh kondisi atlet yang kurang prima saat mengikuti test karena faktor cedera yang belum sembuh dan penurunan berat badan yang masih belum selesai hingga tahap sesi posttest dilaksanakan yang berakibat pada performa atlet dalam mengikuti tes komponenbiomotor dominan

\section{Saran}

Merujuk pada kesimpulan dari hasil penelitian dalam upaya pencapaian peningkatan kemampuan fisik ada beberapa hal penting yang harus diperhatikan. (1) data status awal komponen biomotor dominan atlet merupakan hal penting yang mesti dimiliki penyelengara TC sebagai landasan dan barometer dalam memberikan perlakuan terhadap atlet. (2) Perlu dipahami bagi pihak penyelenggara TC dan atlet bahwa bahwa komponen-komponen atau faktor-faktor pendukung lainya dalam latihan juga perlu diperhatikan diperhatikan kualitasnya. (3) Perlu disadari bahwa program latihan bukanlah satu-satunya faktor penentu keberhasilan dalam meningkatkan prestasi atlet. (4) Faktor-faktor penentu lain seperti recovery, cedera dan gizi bagi atlet tak kalah pentingnya untuk diperhatikan kualitas demi tercapainya peningkatan prestasi. (5) Adanya penelitian dini diharapkan bagi pihak peneyenggara TC yang bersangkutan dan 
atlet sama-sama dapat memahami bahwa program latihan bukanlah penentu utama keberhasilan dalam uapaya meningkatkan prestasi.

\section{UCAPAN TERIMA KASIH}

Ucapan terima kasih peneliti aturkan kepada Beasiswa Bidikmisi dan Comdev \& Outreaching Untan karena telah membantu dalam penyedia dana penelitian. Besar harapan hasil yang dicapai dapat memberikan kontribusi positif terhadap kemajuan institusi.

\section{DAFTAR PUSTAKA}

Adiatmika, I. P. G., \& Santika, I. (2015). Bahan ajar tes dan pengukuran olahraga. Denpasar: Udayana University Press.

Al Faruq, M. M., \& Adiningsih, S. (2017). Pola konsumsi energi, protein, persen lemak tubuh dan aerobic endurance atlet renang remaja. Media gizi Indonesia, 10(2), 117-122.

Arsani, N. L. K. A. (2014). Manajemen gizi atlet cabang olahraga unggulan di kabupaten Buleleng. JST (Jurnal Sains Dan Teknologi), 3(1), 275-287.

Bafirman, H. B. (2013). Kontribusi fisiologi olahraga mengatasi resiko menuju prestasi optimal. Media ilmu keolahragaan Indonesia, 3(1), 41-47.

Bagaswara, Y., \& Priyonoadi, B. (2015). Frekuensi cedera atlet pelatda sepatu roda (perserosi diy). MEDIKORA, 14(2), 1-12.

Fardiansah, D. (2015). Pembinaan olahraga tinju amatir di sasana delta boxing camp kabupaten tegal dan sasana pertina kota tegal tahun 2013. Active: journal of physical education, sport, health and recreation, 4(4), 17141718.

Harsono. (2015). Kepelatihan olahraga (kamsyah adriyani, Ed.). Bandung: Pt Remaja Rosdakarya.

Hasbullah, U. H. A., Setiyowati, E., Noor, Z., \& Aminah, S. (2017). Sistem penyelenggaraan dan pengelolaan makanan bagi atlet sepak bola. Jendela olahraga, 2(1), 148-154.

Jeukendrup, A. E. (2017). Periodized nutrition for athletes. Sports medicine, 47(1), 51-63.

Johansyah, L. (2013). Panduan praktis penyusunan program latihan (1st ed.). Jakarta: PT Raja Grafindo Persada.

Kurdi, S. (2011). Dasar-dasar fisiologi olahraga (1st ed.). Palembang.

Latuheru. (2018). Pengaruh latihan pushup dan beban dumbell ditinjau konsentrasi terhadap kecepatan pukulan straight pada atlet tinju amatir pplp provinsi Maluku. Universitas Negeri Makassar.

Loda, I. M. (2017). Pelatihan memukul dengan beban meningkatkan kecepatan pukulan lurus kiri-kanan dari pada pelatihan mendorong katrol dengan beban. Jurnal edukasi Sumba (JES), 1(2), 78-88. 
Lumba, A. J. F. (2018). Peningkatan kualitas latihan daya tahan atlet tinju. Prosiding seminar nasional iptek olahraga, 1(1).

Mackenzie, B. (2005). 101 performance evaluation test (Brian mackenzie, Ed.). London: electric word plc.

Muis, J. (2016). Interaksi metode latihan dan kecepatan reaksi terhadap kemampuan pukulan atlet tinju kategori youth. Publikasi pendidikan, 6(1).

Owen, A. L., Wong, D. P., Dunlop, G., Groussard, C., Kebsi, W., Dellal, A., ... Zouhal, H. (2016). High-intensity training and salivary immunoglobulin a responses in professional top-level soccer players: effect of training intensity. Journal of strength and conditioning research, 30(9), 24602469.

Pahlevi, R., \& Pustaka, P. T. B. (2012). Dr. Olahraga menjelaskan jenis olahraga olimpiade.

(Online), (https://books.google.co.id/books?id=evZ8DQAAQBAJ).

Parwata, I. M. Y. (2015). Kelelahan dan recovery dalam olahraga. Jurnal pendidikan kesehatan rekreasi, 1(1), 2-13.

Putri, M. W. (2019). Hubungan strenght, endurance, dribbling, passing dan shooting terhadap resiko cedera olahraga. Prosiding seminar nasional fakultas ilmu kesehatan dan sains, 1(1).

Saripin, S. (2017). Tinjauan vo2max pada atlet tinju putera dan puteri club denpal boxing camp Pekanbaru. Jurnal online mahasiswa fakultas keguruan dan ilmu pendidikan universitas Riau, 4(1), 1-9.

Stöggl, T. L., \& Björklund, G. (2017). High intensity interval training leads to greater improvements in acute heart rate recovery and anaerobic power as high volume low intensity training. Frontiers in Physiology, 8, 562.

Syaquro, R. A. (2016). Perbandingan whole body reaction time dan anticipation reaction time antara atlet kata dan kumite cabang olahraga karate. Jurnal terapan ilmu keolahragaan, 1(2), 30-36.

Widhiyanti, K. A. T. (2019). Teknik massage effleurage pada ekstremitas inferior sebagai pemulihan pasif dalam meningkatkan kelincahan. Jurnal pendidikan kesehatan rekreasi, 3(1), 9-17.

Yuniawati, I. (2016). Metode penelitian kuantitatif kualitatif dan campuran untuk menejemen pembangunan dan pendidikan. Bandung: Refika Aditama. 